\title{
Projected Future Changes in Vegetation in Western North America in the Twenty-First Century
}

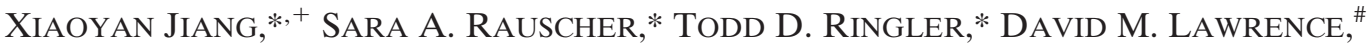 \\ A. PARK Williams, ${ }^{@}$ Craig D. Allen, ${ }^{\&}$ Allison L. Steiner, ${ }^{* *}$ D. Michael CAI ${ }^{++}$ \\ AND NATE G. MCDOWELL ${ }^{@}$ \\ * Theoretical Division, Los Alamos National Laboratory, Los Alamos, New Mexico \\ \# National Center for Atmospheric Research, Boulder, Colorado \\ ${ }^{\circledR}$ Earth and Environmental Sciences Division, Los Alamos National Laboratory, Los Alamos, New Mexico \\ ${ }^{\&}$ U.S. Geological Survey, Fort Collins Science Center, Jemez Mountains Field Station, Los Alamos, New Mexico \\ ** Department of Atmospheric, Oceanic and Space Sciences, University of Michigan, Ann Arbor, Michigan \\ ${ }^{++}$Space Data System Group, Los Alamos National Laboratory, Los Alamos, New Mexico
}

(Manuscript received 10 July 2012, in final form 6 November 2012)

\begin{abstract}
Rapid and broad-scale forest mortality associated with recent droughts, rising temperature, and insect outbreaks has been observed over western North America (NA). Climate models project additional future warming and increasing drought and water stress for this region. To assess future potential changes in vegetation distributions in western NA, the Community Earth System Model (CESM) coupled with its Dynamic Global Vegetation Model (DGVM) was used under the future A2 emissions scenario. To better span uncertainties in future climate, eight sea surface temperature (SST) projections provided by phase 3 of the Coupled Model Intercomparison Project (CMIP3) were employed as boundary conditions. There is a broad consensus among the simulations, despite differences in the simulated climate trajectories across the ensemble, that about half of the needleleaf evergreen tree coverage (from $24 \%$ to $11 \%$ ) will disappear, coincident with a $14 \%$ (from $11 \%$ to $25 \%$ ) increase in shrubs and grasses by the end of the twenty-first century in western NA, with most of the change occurring over the latter half of the twenty-first century. The net impact is a $\sim 6 \mathrm{GtC}$ or about $50 \%$ decrease in projected ecosystem carbon storage in this region. The findings suggest a potential for a widespread shift from tree-dominated landscapes to shrub and grass-dominated landscapes in western NA because of future warming and consequent increases in water deficits. These results highlight the need for improved process-based understanding of vegetation dynamics, particularly including mortality and the subsequent incorporation of these mechanisms into earth system models to better quantify the vulnerability of western NA forests under climate change.
\end{abstract}

\section{Introduction}

Recent evidence suggests that forests in western North America (NA) are vulnerable to climate change. Widespread tree mortality events from semiarid southwestern NA to the high elevation and colder regions in the northern Rocky Mountains have been reported over the past

\footnotetext{
+ Current affiliation: Atmospheric Chemistry Division, National Center for Atmospheric Research, Boulder, Colorado.

Corresponding author address: Xiaoyan Jiang, National Center for Atmospheric Research, Atmospheric Chemistry Division, Boulder, CO 80307.

E-mail: xjiang@ucar.edu
}

decade (Allen et al. 2010). These tree mortality events include deaths throughout entire species ranges associated with drought combined with anomalously high temperatures and widespread bark beetle outbreaks (Breshears et al. 2005; Raffa et al. 2008; Kurz et al. 2008a,b; Bentz et al. 2010). Moreover, background tree mortality rates have doubled over recent decades across western NA, an increase that has been attributed to elevated temperatures (van Mantgem et al. 2009). Such a widespread vegetation change over western NA has important implications for ecosystem services and feedbacks between regional-scale vegetation change, carbon storage, and climate (Allen et al. 2010; Kurz et al. 2008a,b; Betts 2006; Bonan 2008; Running 2008; Peñuelas et al. 2009; Adams et al. 2010; Michaelian et al. 2011). The conversion of forests from 
carbon sinks to sources may influence governmental decisions regarding forest management and greenhouse gas emissions policies (Kurz et al. 2008a; Allison et al. 2009). These changes in mortality events and background mortality rates have emerged as a potential harbinger of rapid broad-scale transitions in vegetation because of climate change.

Climate models project an increase of $1.8^{\circ}-4.0^{\circ} \mathrm{C}$ in mean annual global temperature during the twenty-first century as a result of accumulating atmospheric greenhouse gases under different emissions scenarios (Meehl et al. 2007b). Across western NA, the rise in temperatures is projected to be $2^{\circ}-5^{\circ} \mathrm{C}$ under a medium-level emissions scenario (A1B), exceeding global mean increases, particularly at high latitudes and elevations (Meehl et al. 2007b). Changes in the amount and timing of water availability will likely accompany these temperature increases. A poleward shift of the Hadley circulation and enhanced static stability associated with global warming may increase the frequency and intensity of drought over southwestern NA (Cook et al. 2004; Seager et al. 2007; Seager and Vecchi 2010; Cayan et al. 2010), which could have negative impacts on vegetation (Breshears et al. 2005; Williams et al. 2010, 2013; McDowell 2011). For northwestern NA, a change from snow to rain events, earlier snowmelt, and earlier snowmelt-driven runoff (1-4 weeks earlier; Cayan et al. 2010; Mote et al. 2005; Mote 2006; Stewart et al. 2005; Westerling et al. 2006; Barnett et al. 2008) have already been observed over the past 50 years in response to increasing temperatures over the region. Climate projections suggest intensification of these hydrological trends in the future (e.g., Regonda et al. 2005; Rauscher et al. 2008). Nevertheless, little effort has gone toward assessing whether continued climate change could amplify vegetation change in western NA. If so, what might be the timing and magnitude of future climate-driven vegetation change?

Understanding these questions requires improved knowledge of coupled climate-vegetation dynamics. dynamic global vegetation models (DGVMs), which are comprehensive representations of the complexity of vegetation dynamics including mortality mechanisms, are commonly used to project future vegetation dynamics and their subsequent feedbacks on climate. Although there are limitations associated with our understanding of vegetation mortality mechanisms and vegetationclimate interactions, there have been major efforts over the past decade to develop and improve vegetation dynamics in DGVMs, including how they represent background mortality rates and thresholds associated with water availability, heat stress, productivity, shading/ competition, and growth efficiency (e.g., Cox 2001;
Sitch et al. 2003; Arora and Boer 2006; Delbart et al. 2010; McDowell et al. 2011).

To explore future potential changes in vegetation distributions in western NA in response to climate change, an ensemble of future climate simulations for the period 2005-2100 was performed using the Community Earth System Model version 1.0 (CESM1.0, Gent et al. 2011) with its dynamic vegetation option in the land surface model [the Community Land Model, version 4 (CLM4); Oleson et al. 2010; Lawrence et al. 2011] to simulate future potential changes in vegetation distributions in western NA under a medium-high emissions scenario [Special Report on Emissions Scenarios (SRES) A2; Nakićenović et al. 2000]. To partially span uncertainties in future climate projections using a single model, future sea surface temperature (SST) projections from eight coupled GCMs provided by phase 3 of the Coupled Model Intercomparison Project (CMIP3) (Meehl et al. 2007a) are used as boundary conditions for Community Atmosphere Model (CAM)/ CLM, since SST warming patterns affect tropical and subtropical precipitation patterns, with likely extratropical connections (Xie et al. 2010). These eight coupled GCM SST projections were selected based on several criteria (see methods section). With these experiments, potential impacts of climate change on vegetation in western NA and its associated carbon consequences are assessed. Section 2 describes the models and experimental design. Section 3 presents a limited validation of the modeled vegetation, analysis of the projected vegetation, and climate characteristics from the ensemble simulations. Finally, discussion and conclusions are presented in section 4.

\section{Methods}

\section{a. Model description}

The model utilized here is the atmosphere and land components of the global CESM, which was previously known as the Community Climate System Model (CCSM). To allow for interactions between climate and vegetation, the model was run in a configuration in which the atmosphere model (Community Atmosphere Model) and CLM4.0 are active. The atmosphere was run in its default mode using the finite volume (FV) dynamical core and CAM4 physics with 26 vertical levels (Neale et al. 2010). Since it is computationally expensive to run a global model at a fine spatial resolution for a long period, all the simulations described below were run at a relatively coarse spatial resolution $\left(1.9^{\circ}\right.$ latitude $\times$ $2.5^{\circ}$ longitude) to carry out long-time integrations. The land surface model, CLM4.0 describes the exchange of heat, moisture, and momentum fluxes between the land 
and the atmosphere. In CLM4.0, vegetation coverage is described in each grid cell by fractional areas of "plant functional types," or PFTs. There are a total of 17 PFTs including bare ground, 11 tree and shrub PFTs, three grass PFTs, and two crop PFTs although crops are not considered in DGVM (Lawrence and Chase 2007). The bioclimatic limits for different vegetation types affect the classification of different PFTs (Bonan et al. 2002). For example, needleleaf evergreen tree includes temperate and boreal types based on their climate rules with temperature of coldest month above $-19^{\circ} \mathrm{C}$ and growingdegree days exceeding 1200. CLM4.0 is also extended with a carbon-nitrogen $(\mathrm{CN})$ biogeochemical model that controls carbon dynamics (Thornton et al. 2007). The CN biogeochemical model is prognostic with respect to vegetation, litter, soil carbon and nitrogen states, and vegetation phenology. The simulations in this study use CLM4.0 with $\mathrm{CN}$ and the dynamic vegetation model enabled, which is called CNDV hereafter (Levis et al. 2004; Gotangco Castillo et al. 2012), in which the carbon cycle dynamics are controlled by $\mathrm{CN}$. Thus, changes in vegetation and soil carbon storage can be calculated with the CNDV.

The dynamic vegetation of CNDV is based on the Lund-Potsdam-Jena (LPJ) model (Sitch et al. 2003), including the annual processes of light competition, establishment, and survival as they pertain to the calculations of PFT cover and population. Vegetation change, which may occur as a result of light competition, low growth efficiency, a negative annual carbon balance, heat stress, or when PFT bioclimatic limits are exceeded for an extended period, is represented by a change in the fractional PFT coverage of a grid cell at the end of each simulation year (Sitch et al. 2003). Water availability affects vegetation or PFT coverage through a water stress factor that is calculated for each PFT based on water supply and demand. CLM4CNDV also includes a prognostic treatment of fires based on some simplifying assumptions (i.e., fire occurrence is only dependent on fuel load and litter moisture) and the fire module given by Thonicke et al. (2001). For details regarding the ecological mechanics of vegetation changes, readers are referred to Sitch et al. (2003). It should be noted that CLM4CNDV can only simulate unmanaged vegetation including tree, grass, and temperate and boreal shrub vegetation types (Zeng et al. 2008). Crop PFTs, which represent managed vegetation, are handled separately by the $\mathrm{CN}$ component of the model. In the simulations presented here, crops were not considered in CNDV.

\section{b. Experimental design}

The trajectory of global SSTs and their spatial patterns influence the terrestrial climate response to increasing
TABLE 1. Below is a list of CMIP3 models used in this study and their expansions.

\begin{tabular}{lc}
\hline \multicolumn{1}{c}{ Model } & \multicolumn{1}{c}{ Expansion } \\
\hline NCAR CCSM & National Center for Atmospheric \\
& Research Community Climate \\
System Model, version 3 \\
Centre National de Recherches \\
Météorologiques Coupled Global \\
Climate Model version 3 \\
MPI ECHAM5 & Max Planck Institute ECHAM 5 \\
GFDL CM2.1 & Leophysical Fluid Dynamics \\
& version 2.0 \\
GISS-ER & Goddard Institute for Space Studies \\
& Model E-R \\
HadCM3 & Third climate configuration of the \\
& Met Office Unified Model \\
HadGEM1 & Hadley Centre Global Environmental \\
& Model version 1 \\
MRI CGCM2.3A & Meteorological Research Institute \\
& Coupled General Circulation \\
& Model version 2.3.2a \\
\hline
\end{tabular}

greenhouse gas concentrations, particularly with respect to precipitation patterns (e.g., Xie et al. 2010; Rauscher et al. 2011). To consider the climate response in CAM4/ CLM4CNDV, the model was forced with SST projections from several different climate models, which allows us to assess the impacts of uncertainty in future SST changes. Thus, the results are more robust than relying on just one future SST projection ( $\mathrm{Li}$ et al. 2006).

The set of SST projections are from the CMIP3 archive under the A2 emissions scenario (Meehl et al. 2007a). The A2 emissions scenario was selected as reasonably consistent with trends over recent decades in anthropogenic carbon emissions (Le Quéré et al. 2009). Because limitations in computational resources, only SST projections from eight GCMs (NCAR CCSM3, CNRM-CM3, MPI ECAHM5, GFDL CM21, GISS-ER, HadCM3, HadGEM1, MRI CGCM2.3A—see Table 1) were used in this study. The selection of CNRM-CM3, NCAR CCSM3, and GFDL CM21 is based on the performance of these models in simulating seasonal variations in temperature and precipitation and multiyear variability in Pacific SST on the scale of ENSO (Ropelewski and Halpert 1986; Cayan et al. 2009) over western NA, which is the focal area of this study. It should be noted, though, that the historical skill may not be well related to model future climate change (Brekke et al. 2008). Another rationale was that the models provided different patterns of oceanic conditions (Lin 2007), although most selected models do indicate a trend toward more "El Niño"-like conditions (Meehl et al. 2007b), with the exception of GISS-ER (van Oldenborgh et al. 2005). Because each GCM differs in its representation of physical processes, 
different SST projections contain varying levels of warming with different spatial patterns. The set of eight projections considered here do not span the full range of climate change uncertainty for western NA since each SST scenario is run with the same atmosphere/land model and only the SRES A2 scenario is utilized. Instead, this set of simulations represents a practical first step in assessing the impact of projected climate change uncertainty on the dynamic vegetation response. Using multiple DGVMs in a model intercomparison type protocol would be a better way to address uncertainty in the future studies.

Prior to running the simulations with different SSTs, the vegetation simulated by CLM4CNDV is brought to an equilibrium state. For this study, a 155-yr coupled atmosphere-land (CAM/CLM4CNDV) spinup simulation was performed, in which the initial conditions for CLM4CNDV came from a 200-yr offline CLM4CNDV simulation that cycled the 1948-2004 observed atmospheric forcing (Qian et al. 2006) and started from the end of a twentieth-century CLM4CN transient simulation. One historical (1900-2005) and eight future-year (2005-99) simulations were carried out using CAM4 of CESM coupled with CLM4CNDV. The historical simulation is forced by observed SSTs with the land model initial conditions taken from the end of the spinup run. The results from the end of the historical simulation were then used to initialize the eight SST ensemble simulations in which SST projections were bias-corrected based on observed SSTs (Hurrell et al. 2008). That is, SSTs in future-year simulations were prescribed but land and atmospheric variables evolved together. Prescribed transient $\mathrm{CO}_{2}$ (Nakićenović et al. 2000) and nitrogen deposition rates (Lamarque et al. 2010) were used for the historical and future-year simulations. To be consistent with the future-year SST projections used, prescribed concentrations of greenhouse gas emissions came from the Intergovernmental Panel on Climate Change (IPCC) SRES A2 emissions scenario (Nakićenović et al. 2000). Aerosol concentrations and deposition rates in all simulations were held constant at year 2000 levels. Unless time series are shown, averages representing the late twentyfirst century (2070-99) and the twentieth century (196190) are compared to assess the future changes relative to the present.

\section{Results}

\section{a. Comparison of this study with CMIP3 projections over western NA}

Figure 1a shows the time series of regionally averaged surface air temperature (or 2-m air temperature) changes from 2005 to 2099 for western NA, calculated relative to the year 2005. The CAM4/CLM4CNDV projected ensemble mean surface air temperature is about $0.4^{\circ} \mathrm{C}$ higher than that of the original eight CMIP3 projections from which the SSTs used in this study were derived. There are several possible explanations for the differences. The previous versions of CESM, the Community Climate System Model versions 3 and 4 (CCSM3 and CCSM4), have the tendency to overestimate surface air temperatures, possibly because of the lack of a representation of indirect effects of aerosols, which could cool the earth somewhat over the twenty-first century (Gent et al. 2011). The atmospheric aerosol concentrations used in the experiments are held fixed throughout the twenty-first century at year 2000 values, which could give rise to a higher surface air temperature since aerosol concentrations are projected to increase in the first half of the twenty-first century in the A2 emissions scenario, although sulfate concentrations are generally low over western NA (Nakićenović et al. 2000).

No apparent trend in the projected precipitation is observed when averaged over the whole western NA (Fig. 1b), similar to the eight original CMIP3 simulations. Subregional analysis of precipitation changes over southwestern NA and northwestern NA (Fig. 2) shows that the CESM simulations produce slightly more future precipitation over southwestern NA, as compared to the ensemble mean of CMIP3 simulations and CCSM3 simulations (Seager et al. 2007; Seth et al. 2011). The absence of drying over parts of western NA, particularly over California and Nevada, is also present in the CMIP5 CCSM4 simulations (Meehl et al. 2011), which is a version of the model similar to that used here. Therefore this feature is likely tied to the new atmospheric model formulation. This response appears to be related to lower low-level geopotential heights in the northern Pacific and higher heights over North America, a Pacific-North America (PNA)-like teleconnection pattern that funnels moisture into the defined "southwestern NA" box in winter (Fig. 3). In contrast, the increase in summer low-level geopotential heights tends to enhance dryness. Note, however, that the range of projected precipitation changes over northwestern NA is roughly as broad as the CMIP3 simulations. Overall, the simulations exhibit a large range of potential future climates, providing us with multiple realizations of future climate change to assess potential future changes in vegetation.

\section{b. Present-day vegetation simulation}

The global performance of CNDV in simulating present-day vegetation coverage is evaluated by Gotangco Castillo et al. (2012). The simulated PFTs in the simulations presented here are nearly identical to those presented 
(a)

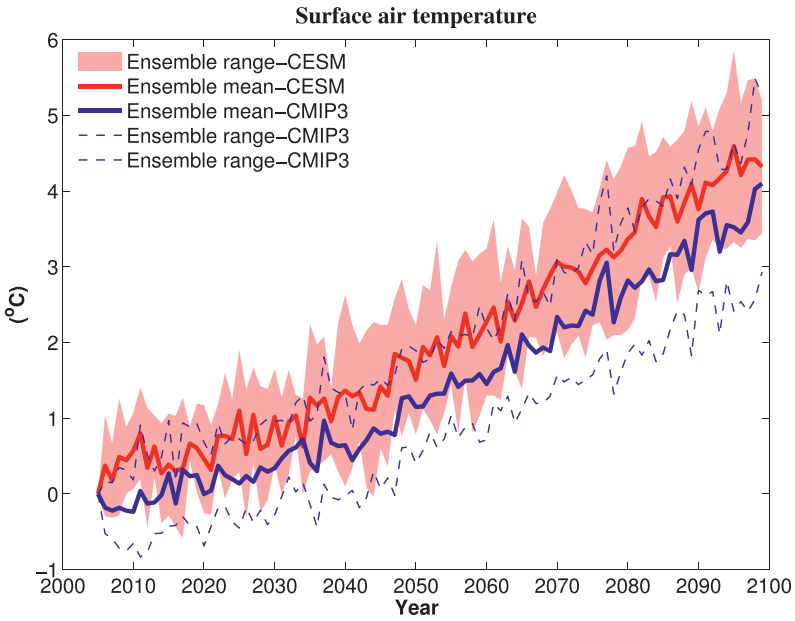

(b)

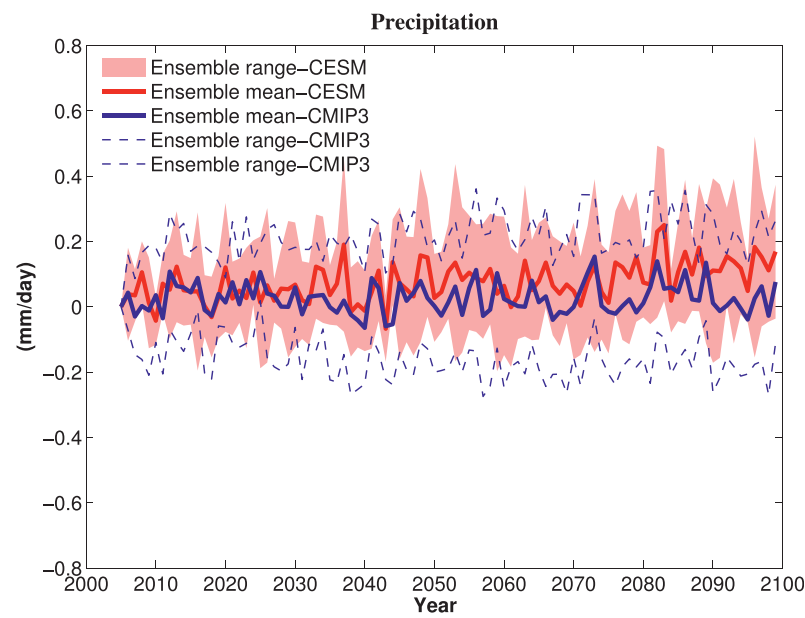

FIG. 1. Time series for 2005-99 of projected annual mean (a) surface air temperature and (b) precipitation change over western NA, relative to year 2005 values. Shaded area represents the ensemble range of eight CESM runs. Dashed blue lines show the ensemble range of eight CMIP3 projections. Thick red and blue lines represent the eight-model mean changes for CESM runs and CMIP3 projections respectively.

by Gotangco Castillo et al. (2012) (western North America shown in Fig. 4; their Fig. 2). Overall, CNDV simulates a reasonable present-day distribution of PFTs compared to the derived historical PFT distribution. The time series of PFT data over the twentieth century was generated as a combination of current-day satellitederived values and potential vegetation scaled by land use history from the Global Land Model of Hurtt et al. (2006). The details can be found in Lawrence et al. (2012). The performance of CNDV is significantly improved from the older versions, CLM3DGVM (Bonan and Levis 2006) and CLM3.5DGVM (Oleson et al. 2008). For example, deciduous tree cover was too low over the (a) Northwestern NA

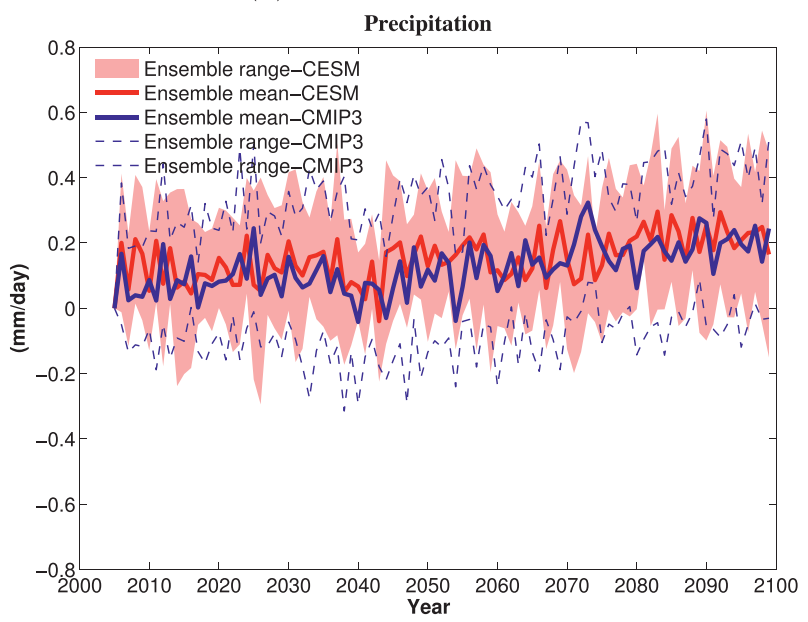

(b) Southwestern NA

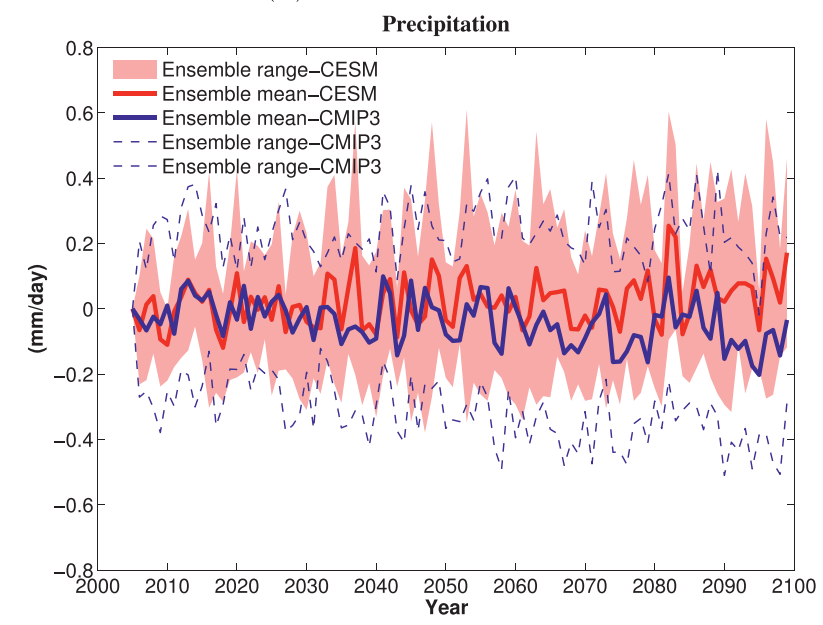

FIG. 2. Time series for 2005-99 of projected annual precipitation change over (a) northwestern and (b) southwestern NA, relative to year 2005 values. Shaded area represents the ensemble range of eight CESM runs. Dashed blue lines show the ensemble range of eight CMIP3 projections. Thick red and blue lines represent the eight-model mean changes for CESM runs and CMIP3 projections respectively.

eastern United States in CLM version 3 (Bonan and Levis 2006) but coverage has increased in the latest version. However, the model underestimates high-latitude vegetation cover in the tundra, a known bias in CLM owing to excessively high simulated soil moisture stress in that region (Lawrence et al. 2011). Given the in-depth evaluation performed by Gotangco Castillo et al. (2012) and the fact the DGVM used in this study is based on the LPJ DGVM, which has been extensively used and evaluated by many earlier studies (i.e., Sitch et al. 2003), here, the model performance in simulating the presentday vegetation distribution over western NA is briefly evaluated. 

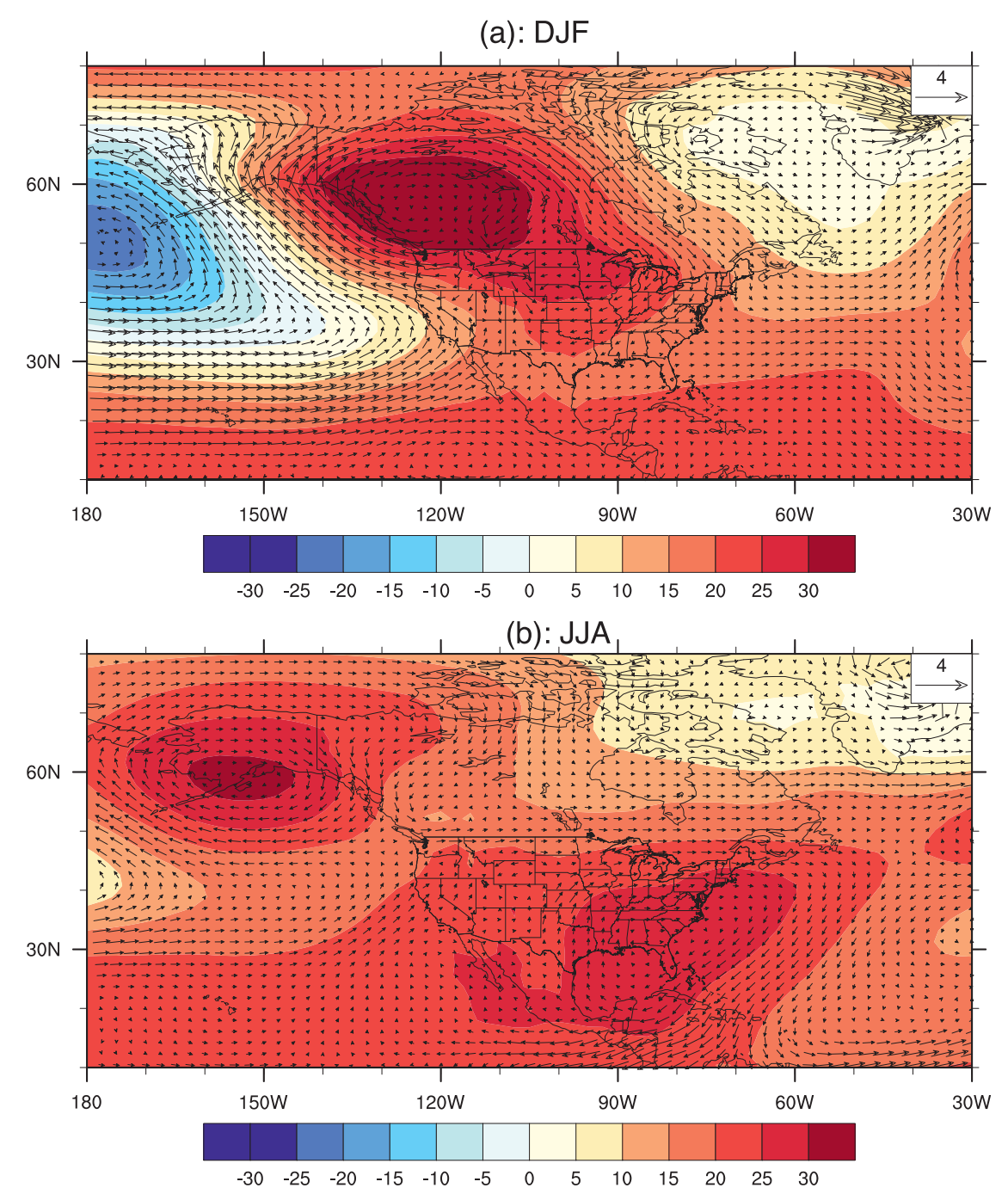

FIG. 3. Changes in (a) winter [December-February (DJF)] and (b) summer [June-August (JJA)] geopotential heights (m) and wind fields at $850 \mathrm{hPa}$ between 2070-99 and 1961-90.

Figure 4a shows the simulated present-day dominant PFTs (needleleaf evergreen tree, deciduous tree, shrub, and grass) over western NA (see box in Fig. 4c for area). With the exception of grasses, the area-averaged coverage of needleleaf evergreen tree, deciduous tree, and shrub PFTs is within a few percent of the observed, whereas it underestimates grasses over this region because of the overestimation of bareground, trees, and shrubs, an issue common with the vegetation model used in this study (Bonan et al. 2003; Sitch et al. 2003). The model-simulated spatial coverage of needleleaf evergreen trees over this region (Fig. 4d) agrees with the satellite-derived coverage (Fig. 4c), although there are some regional details (i.e., the coverage over the west coast) that are not well captured by the model. These differences may be due to the model spatial resolution, which does not adequately represent the controls of the complex western NA topography on vegetation distribution. As a result, the heterogeneous spatial distribution of surface air temperature and precipitation are smoothed compared to observations, which then impacts the resulting vegetation distribution.

A comparison of the coverage of the western NA PFTs (needleleaf evergreen tree, shrub, and grass; deciduous tree coverage is too small to be shown) between the observations and the simulations (Fig. 4b) shows that there are no large trends over the twentieth century, although there is a slight increasing trend in the modeled needleleaf evergreen tree coverage, which could be related to the model spinup or to temperatures and/or atmospheric carbon dioxide increasing throughout the twentieth century. 


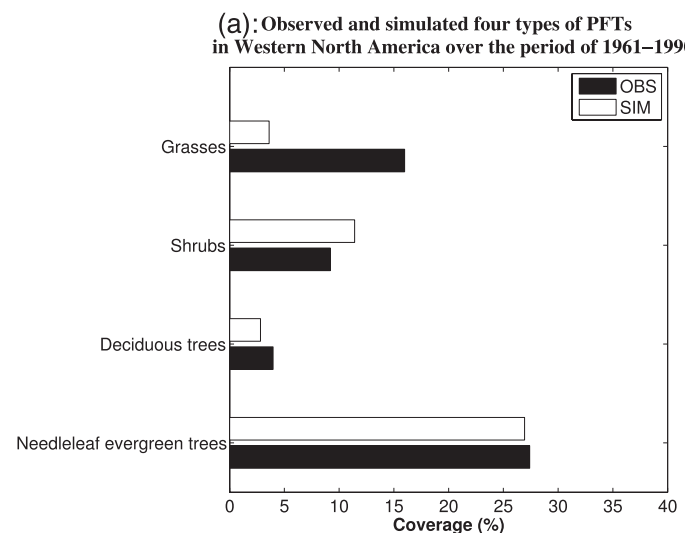

(c): Satellite derived PFT

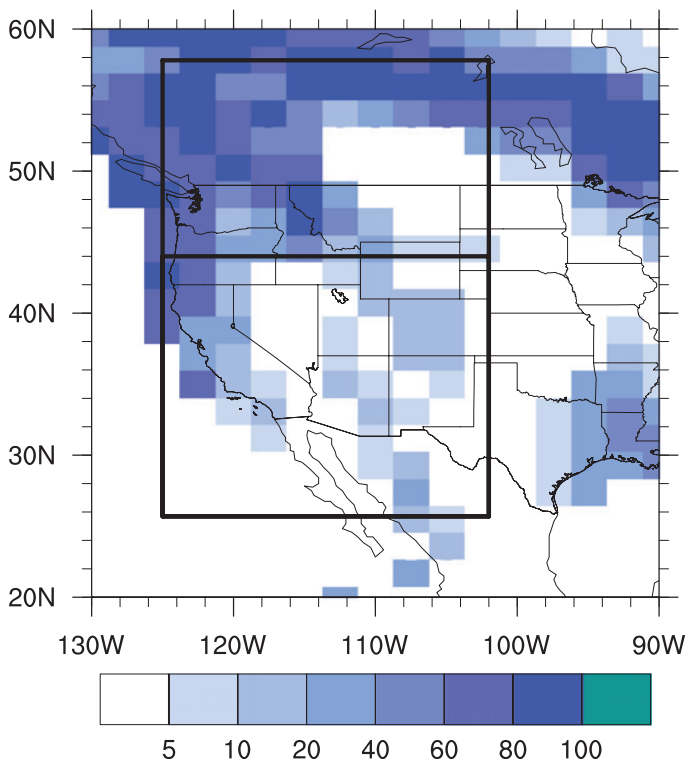

(b): PFT coverage

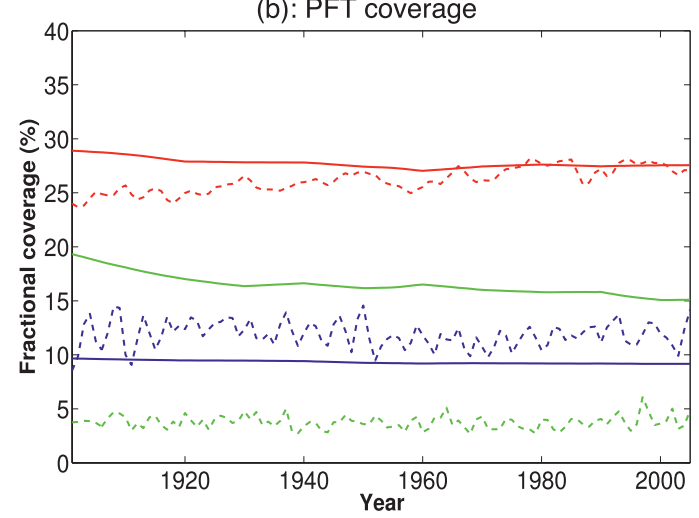

(d): Simulated PFT

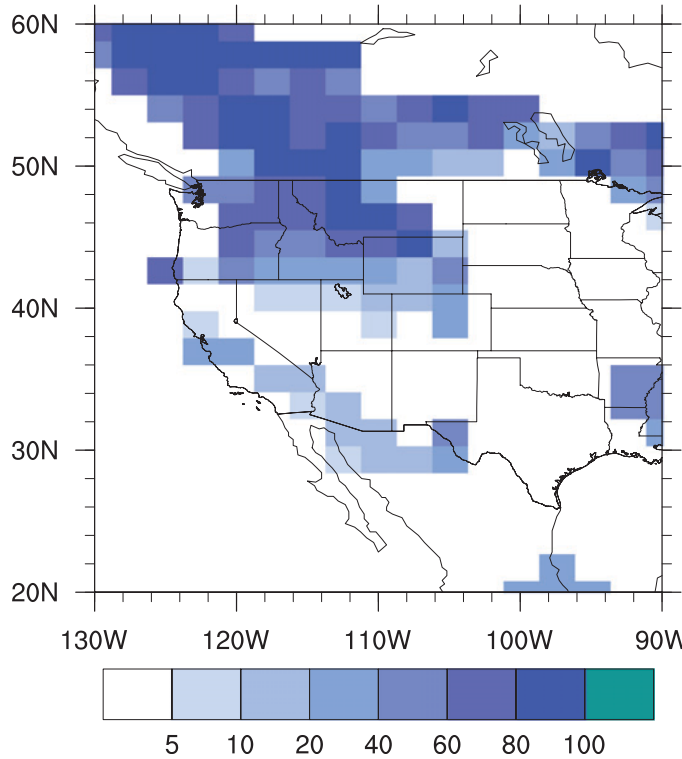

FIG. 4. (a) Observed and simulated four types of PFTs in western NA over the period of 1961-90. Observations are derived from satellite measurements (Lawrence and Chase 2007). (b) Satellite-derived (solid lines) and modelsimulated (dashed lines) PFT coverage for needleleaf evergreen trees (red), shrubs (blue), and grasses (green) in the twentieth century. Spatial coverage of (c) satellite-derived and (d) model-simulated needleleaf evergreen tree in 2000 in western NA. Western NA is defined by the large outer box in Fig. 4c, which is further divided by a line into southwestern NA and northwestern NA.

Overall, the model appears to be able to reproduce the historical vegetation distribution, but the regional details and dynamics differ owing to the coarse model resolution. Comparing with some regional reports about vegetation changes, such as the vegetation mortality events that are documented in Allen et al. (2010), the model does not capture small- or local-scale events. This is not surprising since we are using CLM coupled to CAM, and the atmosphere evolves freely with forcing only from observed SSTs. Therefore, historical climate anomalies (e.g., drought) associated with mortality or vegetation change may not necessarily be reproduced. The model resolution deployed here also limits the model's ability to reproduce the small-scale, local events reported by Allen et al. (2010). Further, the CLM4CNDV model does not mechanistically or explicitly represent tree mortality. Instead, as is common with DGVMs used in global models [i.e., TRIFFID (Top-down Representation of Interactive Foliage and Flora Including Dynamics), DGVM, Cox 2001] of this class, it calculates the suitability for survival or establishment of a particular PFT based on the PFT's bioclimatic limits and competition processes across PFTs. Note that mechanistic vegetation mortality modeling (i.e., considering hydraulic failure and carbon starvation, Fisher et al. 2010; McDowell et al. 2011) remains a vexing problem in ecosystem 
(a)

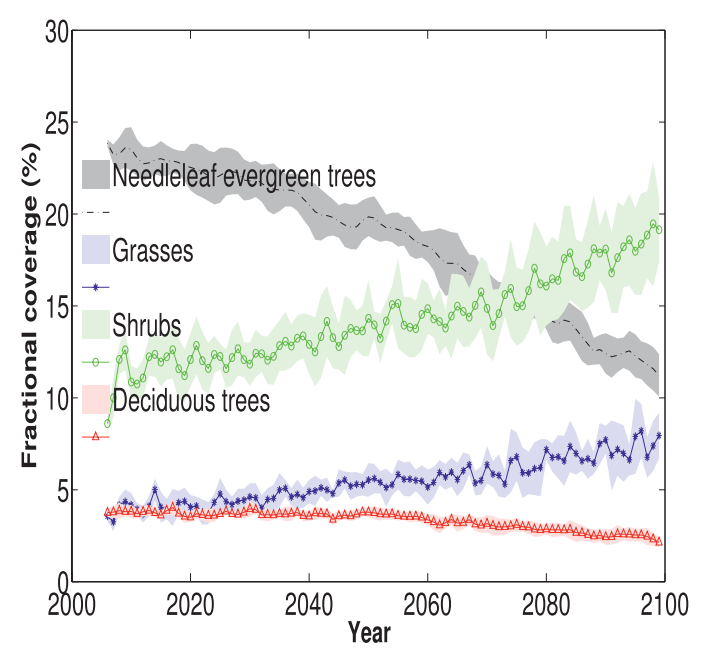

(c)

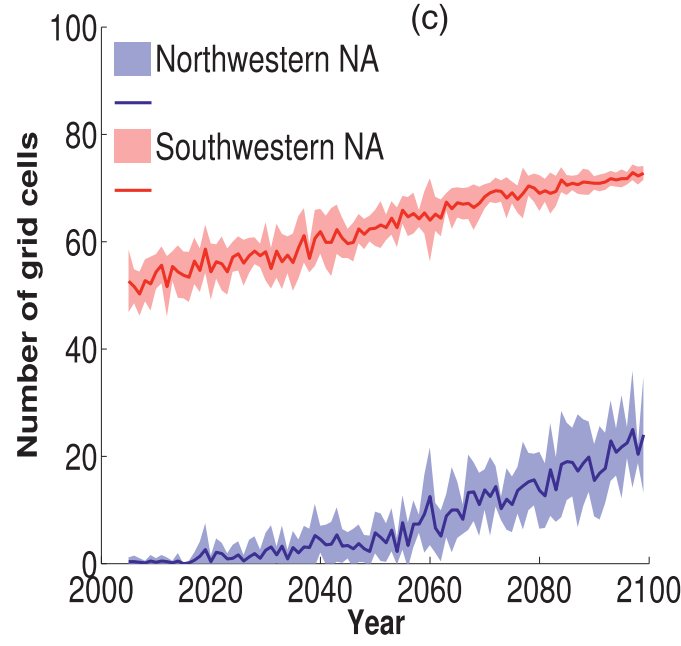

(b)

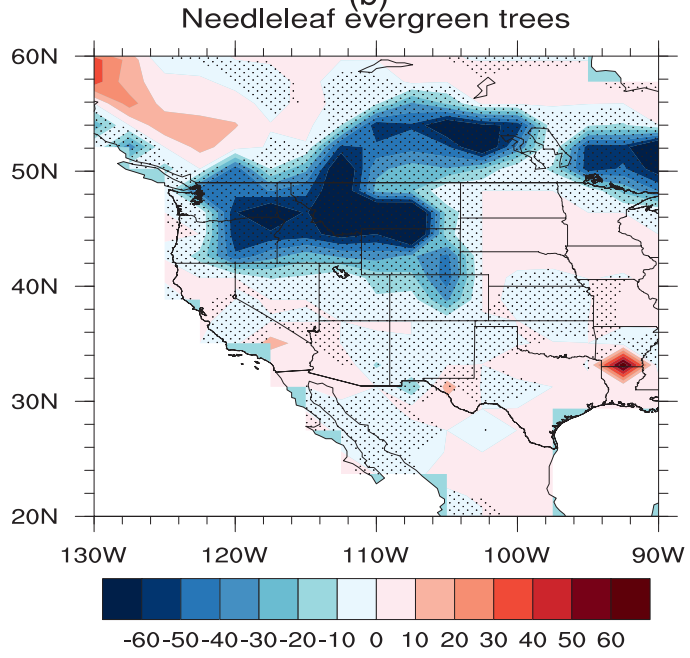

(d)

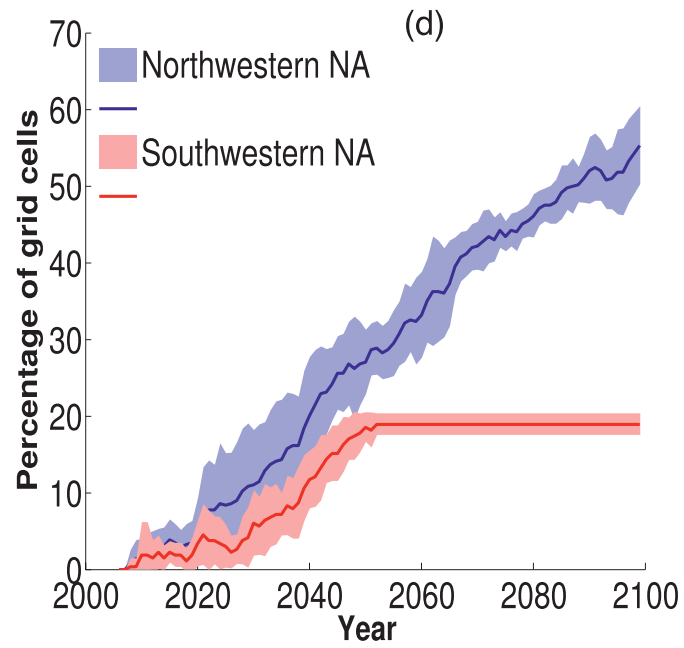

FIG. 5. (a) Time series for 2005-99 of spatially averaged fractional coverage of four dominant types of PFTs over western NA. Shaded area represents the ensemble range of eight CESM runs, and lines are the eight-model means. (b) Spatial distribution of changes in needleleaf evergreen tree coverage between 2070-99 and 1961-90. Stippling represents the area where the ensemble mean change is larger than the intermodel standard deviation. The ratio of mean to standard deviation can be related to formal tests of statistical significance and confidence intervals, if the individual model results were to be considered a sample. (c) Time series of the number of grid cells that experience heat stress mortality in northwestern and southwestern NA. (d) The percentage of vegetated grid cells (with at least $1 \%$ coverage of needleleaf evergreen tree) that experiences more than $20 \%$ reduction in needleleaf evergreen tree coverage in northwestern and southwestern NA, relative to 2005. Heat stress mortality is defined in section $3 \mathrm{~d}$.

modeling and that the limitations of this and equivalent DGVM approaches to vegetation mortality currently in use need to be kept in mind when interpreting the potential future vegetation changes shown in this study.

\section{c. Projected vegetation changes over western NA}

The simulated future response of vegetation coverage of four dominant plant functional types (PFTs) in western NA to future climate change is shown in Fig. 5. There is a broad consensus across the different climate trajectories simulated in our ensemble for a decrease (from an average of $25 \%$ in 2005 to an average of $11 \%$ in $2100)$ in needleleaf evergreen tree coverage and an increase (from average of $11 \%$ in 2005 to an average of $25 \%$ in 2100) in shrubs and grasses beginning around the year 2030 (Fig. 5a). An analysis of changes in spatial coverage (Fig. 5b) indicates that the area covered by the needleleaf evergreen tree PFT shrinks and is partly replaced by shrubs or grasses over northwestern NA between $40^{\circ}$ and $59^{\circ} \mathrm{N}$. A decrease in tree coverage over 
southwestern NA also occurs, although it is more difficult to discern the absolute changes since the overall tree coverage is lower compared to northwestern NA (Figs. 4c,d). As described in section 2a, CLM4CNDV also includes fire treatment; an analysis of the annual burned areas in the study domain shows a small fraction $(\sim 0.5 \%-0.9 \%)$ of the total area in western NA is projected to experience vegetation removal by fires. Thus, the following analysis mainly focuses on vegetation changes caused by climate change.

\section{d. Vegetation change and climate change linkage}

The vegetation changes shown in Figs. 5a,b are the result of the interaction of several climatic factors, in particular temperature and water availability. Vegetation dies when heat stress or heat mortality occurs in CLM4CNDV. In reality, temperature partially determines photosynthetic and respiration rates of vegetation, thus under very hot conditions, plants become stressed and may die (Joos et al. 2001; Adams et al. 2009; McDowell 2011). In CLM4CNDV, the heat damage mortality effect is parameterized using an annual accumulation of days above a PFT specific temperature base $\left(23^{\circ} \mathrm{C}\right.$ for needleleaf evergreen trees), with heat mortality increasing linearly and reaching unity at or above 300 degree-days above the threshold value (Sitch et al. 2003; Levis et al. 2004).

Figure 5c shows a time series of the number of grid cells in northwestern and southwestern NA that exceed the heat stress (or heat damage) mortality threshold as defined above in northwestern and southwestern NA. The total numbers of grid cells are 80 and 100 in northwestern and southwestern NA, respectively. Figure 5c shows that heat stress starts to increase in both regions around 2030 when the average temperature increase is projected to exceed $1^{\circ} \mathrm{C}$ over late twentieth-century levels (Fig. 1a). By the end of 2099, about 24 grid cells (or $30 \%$ of grid cells) over northwestern NA are projected to exceed the heat stress mortality threshold in the simulations. In southwestern NA, the heat stress mortality threshold is exceeded in a majority of grid cells (about 72 of 100 or $72 \%$ ) because of much higher mean temperatures simulated in this region. Correspondingly, about $55 \%$ (or 33 grid cells) and 20\% (or 7 grid cells) of the needleleaf evergreen tree grid cells, which are defined when there is $>=1 \%$ needleleaf evergreen tree coverage, in southwestern and northwestern are projected to experience $20 \%$ or more loss of needleleaf evergreen trees (Fig. 5d). Over northwestern NA, the results indicate that heat stress mortality is responsible for about $70 \%$ of projected loss of needleleaf evergreen trees. Note that in Fig. $5 \mathrm{~d}$ the change over southwestern NA stops at $20 \%$; this is because only about $20 \%$ of grid cells in that region have $20 \%$ or more needleleaf evergreen tree coverage. Our model results therefore suggest that most needleleaf evergreen trees in southwestern NA will be lost. However, we should note that, in reality, topographically complex portions of the southwest that are not well represented in our fairly coarse-resolution simulations may remain cool and wet enough in the future (high elevation, cold-air drainages, moist valleys) to sustain needleleaf evergreen trees.

Besides temperature, other climatic variables such as water availability influence vegetation growth by controlling net vegetation carbon balance (McDowell 2011; Sitch et al. 2003; Levis et al. 2004). In CLM4CNDV, mortality occurs when the annual net primary production (NPP) drops below zero. NPP declines because of both water limitations on photosynthesis and increases in maintenance respiration costs (Sitch et al. 2003). Although precipitation is traditionally considered to be an important climatic driver of vegetation productivity, water availability more accurately reflects vegetation water stress drivers (Stephenson 1990). Here, water availability is represented by a water balance coefficient (WBC) - the difference between mean monthly precipitation and potential evapotranspiration (Churkina and Running 1998), where potential evapotranspiration is a function of mean temperature and net solar radiation (Priestley and Taylor 1972). Thus, the WBC reflects the interactions of energy and water and can be used to estimate how much usable energy and water are available simultaneously to plants (Stephenson 1990). Figure 6 shows the annual cycle of the WBC as well as precipitation, surface air temperature, snow depth, and runoff for the period 2070-99 compared to 1961-90 for the northwestern and southwestern NA regions. The shaded areas in the figure represent the ensemble range of eight simulations.

Over northwestern NA, where large reductions in needleleaf evergreen tree coverage are projected to occur, the ensemble mean changes in WBC are small for most of the year with the exception of summer, when the changes are strongly negative. This maximum decrease in WBC coincides with a maximum in the ensemble mean surface air temperature change. The marked summer peaks in WBC deficit and temperature are intimately related to hydrological changes (i.e., precipitation, snow depth, and runoff) over the region. First, Fig. 6 shows that the simulated warming over northwestern NA results in more and earlier snowmelt as reflected in decreased snow depth and increased runoff in spring. In response to reductions in snow cover, surface albedo decreases by 0.05 in the winter and spring seasons. This increased snowmelt amplifies the rate of local-to-regional warming (Chapin et al. 2005; Euskirchen et al. 2007) through snow-albedo 

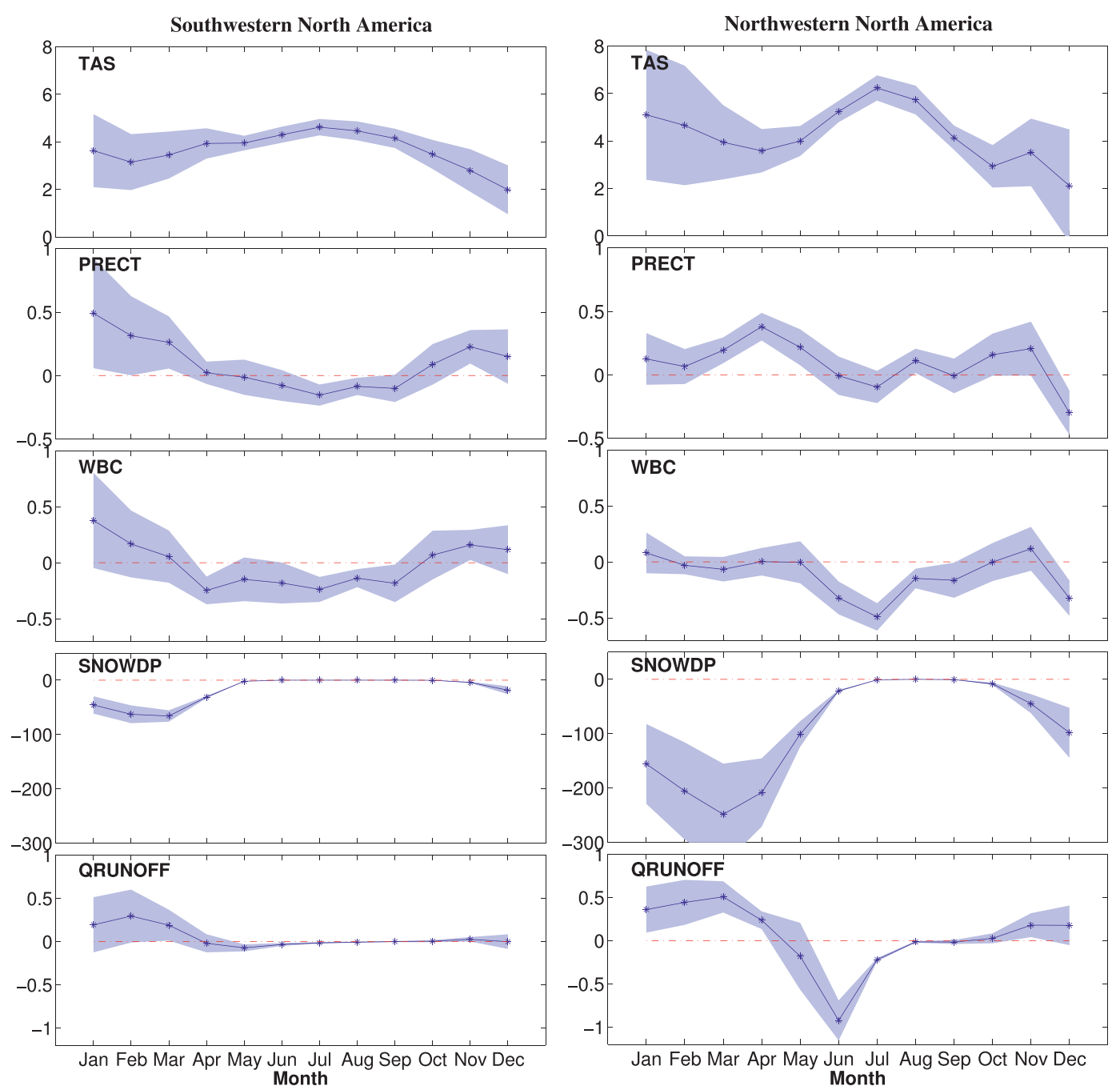

FIG. 6. Projected changes in monthly surface air temperature $\left(\mathrm{TAS},{ }^{\circ} \mathrm{C}\right)$, precipitation $\left(\mathrm{PRECT}, \mathrm{mm} \mathrm{day}^{-1}\right.$ ), water balance coefficient (WBC, mm day ${ }^{-1}$ ), snow depth (SNOWDP, mm), and total runoff (QRUNOFF, $\mathrm{mm} \mathrm{day}^{-1}$ ) over land for 2070-99, relative to the 1961-90 mean. (left) The results for southwestern NA and (right) the results for northwestern NA are shown. Shaded area represents the ensemble range of eight CESM runs. Red dashed line shows the zero baseline.

feedback (Winton 2006) and summer water deficits because of early spring runoff. The warming and associated hydrologic changes such as declining snowpack water content, earlier spring snowmelt and runoff (Fig. 6), and a consequent lengthening and intensification of the summer dry period stress vegetation over western NA in the simulations, increasing vegetation mortality rates through limits on photosynthesis or vegetation growth. Second, the vegetation changes themselves appear to be amplifying the temperature increases over northwestern NA as shown in Fig. 7, where the region of largest summer temperature change is broadly coincident with the region transitioning from forest to shrub and grass cover. This change in vegetation cover decreases the latent heat flux by reducing canopy evaporation and transpiration (Fig. 8), thereby increasing the sensible heat flux and surface air temperatures in the CLM4CNDV simulations, creating a feedback on the heat stress experienced by the vegetation.

As noted earlier, southwestern NA shows relatively smaller changes in vegetation cover compared to northwestern NA, mainly because of less initial vegetation cover over the region. This results in less amplification in the temperature response in southwestern NA $\left(\sim 3^{\circ} \mathrm{C}\right.$ versus $5^{\circ} \mathrm{C}$ in northwestern NA) (Fig. 6), and relatively minor snow-albedo feedbacks because of the smaller land area covered by snow. It should be noted that the WBC change is positive in winter over southwestern 


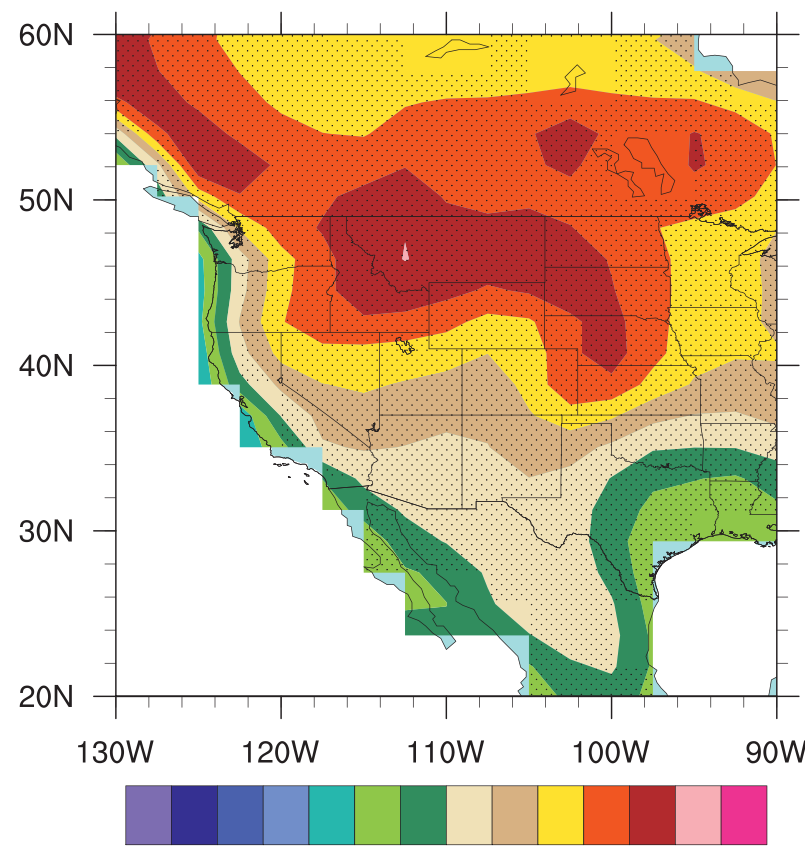

11.522 .533 .544 .555 .566 .57

FIG. 7. Projected changes in summer (JJA) surface air temperature $\left({ }^{\circ} \mathrm{C}\right)$ over western NA between $2070-99$ and 1961-90. The meaning of stippling is the same as in Fig. 2.

NA as a result of higher winter precipitation in the future scenario simulations. Despite this positive influence on WBC, warming and associated increased potential evapotranspiration decrease spring and summer water availability over southwestern NA (Fig. 6).

In the experiments, vegetation change and productivity depend on multiple environmental parameters that co-occur with climate change. The relationship between water availability (WBC), surface air temperature, and vegetation net primary production (NPP) is shown in Fig. 9a for the years from 2005 to 2099 over western NA. NPP declines with both decreasing WBC and increasing temperature over the twenty-first century, despite rising atmospheric $\mathrm{CO}_{2}$, which benefits plants via increased photosynthesis and reduced stomatal conductance. The regional ensemble mean response (big circles) suggests that vegetation productivity holds fairly steady until mid-twenty-first century before it begins to decline toward the end of the twenty-first century as temperature, water stress, and associated changes in vegetation composition outweigh the beneficial impacts of $\mathrm{CO}_{2}$ fertilization. This is particularly true for northwestern NA where the water deficits are enhanced as the region warms (Fig. 9b). The higher temperatures combined with the decrease in WBC result in a reduction in tree coverage over northwestern NA in the experiments. Over southwestern NA, NPP is

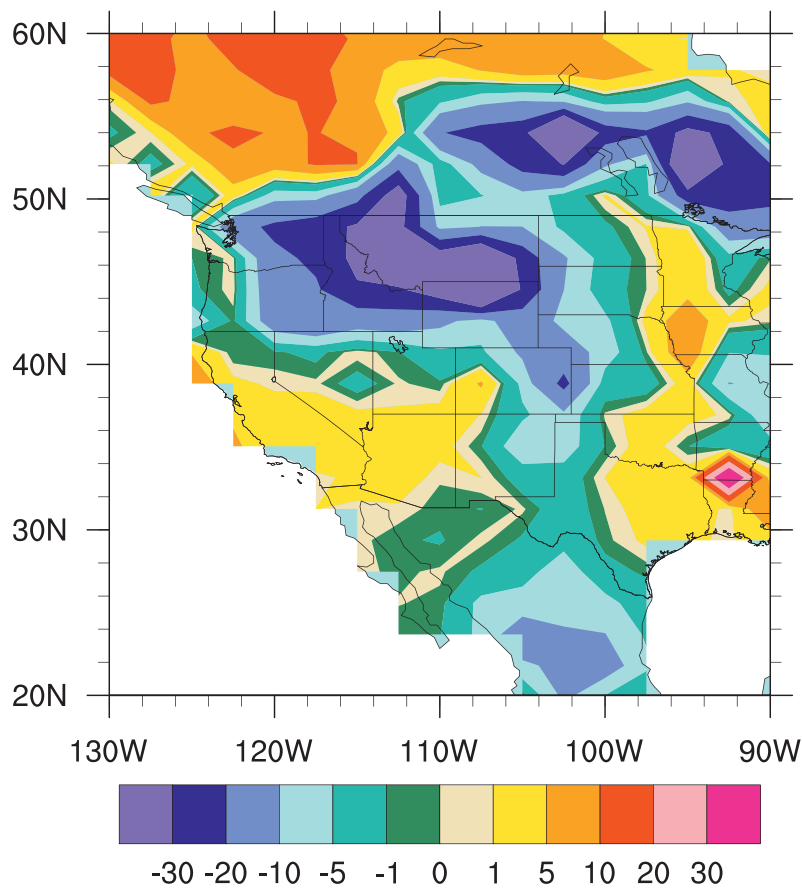

FIG. 8. Changes in summer (JJA) canopy evapotranspiration over western, NA between 2070-99 and 1961-90.

projected to decrease throughout the twenty-first century (Fig. 9c).

\section{e. Potential impacts on carbon storage}

As mentioned in the "methods" section, the use of $\mathrm{CN}$ allows us to assess how vegetation and soil carbon storage changes in response to climate change and climate change associated vegetation change. Below, the model-projected changes in total vegetation and ecosystem (vegetation and soil) carbon storage are assessed. The projected widespread shift from needleleaf evergreen tree forest to shrub and grass-dominated landscapes throughout western NA has substantial consequences for carbon storage (Fig. 10). Western U.S. forests are responsible for $20 \%$ to $40 \%$ of total U.S. carbon sequestration (Pacala et al. 2001), though disturbances are a significant threat to carbon storage in this region (Potter et al. 2006). The model results indicate that by 2100 , there may be a $3.3 \mathrm{GtC}$ (or $35 \%$ ) reduction in the vegetation carbon over western NA, where $27 \%$ of the land is covered by forests (here, forests are defined as the regions with more than $90 \%$ tree coverage) over western NA owing to the transition from forests to grasses and shrubs. In addition to vegetation carbon loss, there may be an additional $2.5 \mathrm{GtC}$ (or 13\%) soil carbon loss because of both increased necromass and accelerated decomposition rates with higher temperatures. If the bias in simulated grass coverage is taken into account, 


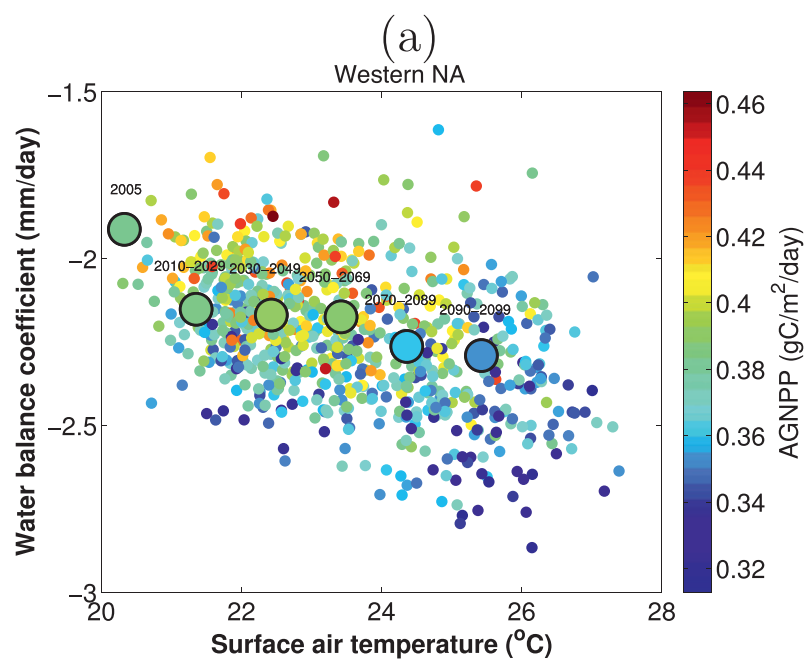

(b)

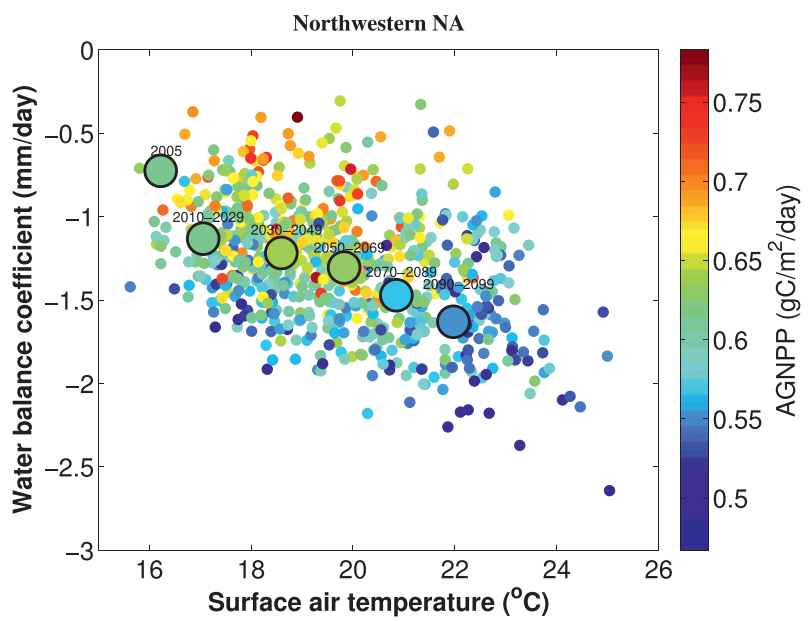

(c)

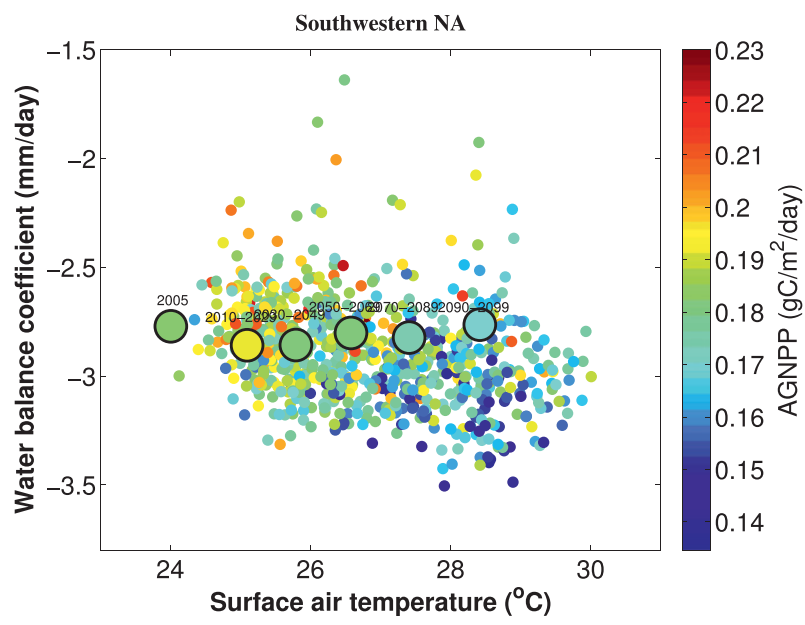

FIG. 9. Climatic control on vegetation growth [or relationship among WBC, surface air temperature, and Above Ground Net Primary Productivity (AGNPP)] over (a) western NA, (b) northwestern NA, and (c) southwestern NA in the twenty-first century. there is only a small overestimation (about $0.2 \mathrm{GtC}$ ) in projected vegetation carbon loss as forests are typically more than 10 times as effective as grasslands at storing carbon per hectare (Potter et al. 1999; Scurlock et al. 2002). The projected loss of forest carbon from 2005 to 2100 is equivalent to 16 years of fossil fuel emissions from the United States (Friedlingstein et al. 2010). The total loss from vegetation changes and soil is also about $15 \%$ of the total $37.2 \mathrm{GtC}$ carbon pools over the continental United States as reported by Potter et al. (2006). It should be pointed out here that future warming climate also leads to positive net ecosystem exchange (NEE) starting from the mid-twenty-first century, which would contribute to additional carbon loss because of climate change.

\section{Discussion and conclusions}

In this study, the potential effects of future climate change on vegetation changes over western NA under the A2 emissions scenario are studied using the CESM. Irrespective of the different SST boundary conditions imposed, all eight simulations project a shift of treecovered landscape to shrubs and grasses dominated landscape over western NA because of future warming and related increases in water deficits. The analysis of the climatic controls on vegetation growth in the model suggests that heat stress resulting from projected temperature increase is the dominant driver of the simulated decrease in needleleaf evergreen tree coverage over western NA. In addition, the indirect effects of increased evaporative demand (and associated stomatal closure) and the longer duration of snow-free periods as a result of earlier and faster snowmelt also appear to be associated with model projected vegetation changes.

The model projections are consistent with observed trends of increasing mortality throughout western NA that is associated with rising temperatures (van Mantgem et al. 2009). Since the heat stress effect appears to be prominent in future climate simulations utilizing the LPJ DGVM (on which the CESM DGVM is built), DGVM formulation clearly has a large impact on simulated vegetation change. One example is that when the LPJ DGVM was used in Sitch et al. (2008), it also simulated a decrease in vegetation (tree) coverage and soil carbon stock in the high northern latitudes.

Results are shown for summer (June, July, and August) means from 2005 to 2099. Big circles represent ensemble means of eight CESM runs for the periods highlighted on the figure. Colors represent AGNPP values. 


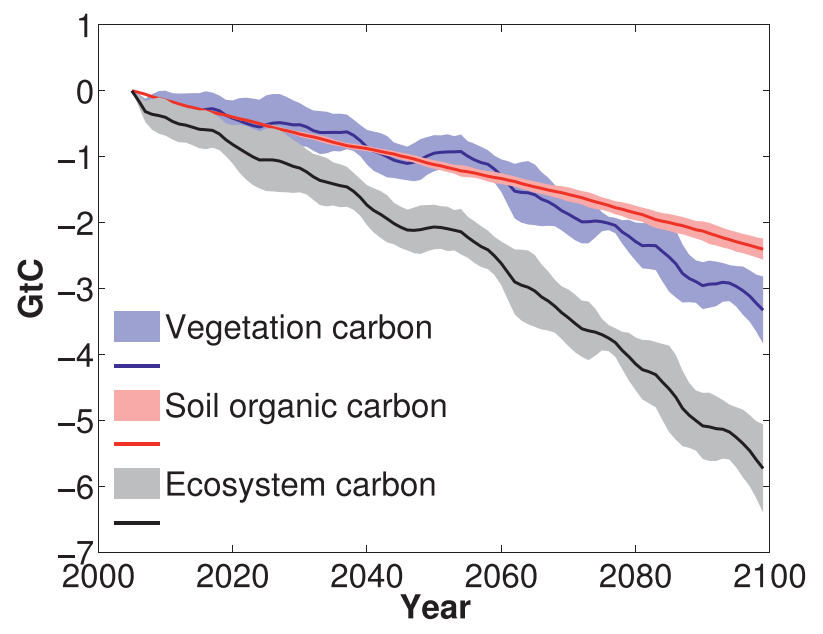

FIG. 10. Time series of projected changes in vegetation carbon, soil organic carbon, and ecosystem carbon (vegetation and soil organic carbon) stocks for the period of 2005-99 over western NA. Changes are relative to year 2005 values. Shaded area represents the ensemble range of eight CESM runs.

In the simulations, there was some northward expansion of grasses, but not trees as in other DGVM climate change simulations (i.e., Gotangco Castillo et al. 2012). There is a bias in simulated vegetation cover over boreal regions, which could be in part related to the soil moisture problem in the CLM model (Lawrence et al. 2011).

Our results contrast with other modeling studies that indicate the Northern Hemisphere is greening because of warming and $\mathrm{CO}_{2}$ fertilization. For example, some studies (e.g., Cox et al. 2004; Jones et al. 2010) found that vegetation carbon was projected to increase in the forested regions of the Northern Hemisphere mostly as a result of $\mathrm{CO}_{2}$-fertilization of photosynthesis under "business as usual" or other idealized emission reduction scenarios. Warming could also lead to a longer snow-free period and therefore extend the growing season in the boreal regions (e.g., Harris et al. 2006). Bergengren et al. (2001) simulated a poleward migration of the boreal forest into tundra related to the albedo feedback and spread of temperate grasslands into the southern boreal zone owing to greater summertime warming. These studies used different climate models and vegetation models. Also, this work differs from other studies by using different future SST projections that play an important role in projecting future climate change, in particular precipitation and temperature. Seager et al. (2007) already showed that most of the global climate models project a drying southwestern United States in the future. This could have an important implication on the forests in this region. The model simulations forced by different future SST projections did reproduce the water deficiency in this region. Thus, the experiments suggest that the increased heat and water stresses associated with warming (the so-called radiative effect-e.g., Notaro et al. 2007) could outweigh the benefits of longer growing seasons, atmospheric $\mathrm{CO}_{2}$, and nitrogen fertilization. The negative impacts of increased heat and water stress on vegetation have been observed over the past 30 years on all six forested continents (e.g., Allen et al. 2010; van Mantgem et al. 2009; Ciais et al. 2005). Similarly, latitudinal trends in conifer growth have shown that the northernmost populations experience the maximum benefit of higher temperatures, with more southerly and drier regions exhibiting declining productivity above a temperature threshold (Williams et al. 2010, 2011). While some regions in the Northern Hemisphere may have experienced greater productivity in recent decades (Goetz et al. 2005; Beck et al. 2011), this productivity may be coincident with increased mortality, and the balance of the two may become negative over the twenty-first century.

The projected total carbon loss in the simulations is $5.8 \mathrm{GtC}$, with $57 \%$ lost from the vegetation stock and $43 \%$ from the soil carbon stock. The potential carbon losses through vegetation change may be underestimated because they do not include other disturbances (e.g., Chambers et al. 2007; Zhao and Running 2010; Adams et al. 2011; Hicke et al. 2011; Liu et al. 2011) that are likely to increase with climate change, most notably insect attacks (e.g., Kurz et al. 2008a,b; Pfeifer et al. 2011; Edburg et al. 2012). Considering these caveats, the results further highlight the potential vulnerability of forests over western NA to future climate change. The consequent effects on carbon storage due to tree reduction in this region have the potential to convert the forests of western NA from a net carbon sink to a net carbon source. Thus the projected future climate change would magnify the threats to human communities and ecosystems over western NA and could substantially increase management challenges in preserving forests and reducing greenhouse gas emissions. The potential impacts of future climate change on regional vegetation change underscore the need to develop adaption strategies to improve the resistance and resilience of forests to projected increases in climate stress (Seppälä et al. 2009; Williams et al. 2010).

There are substantial uncertainties in the model projections. Besides uncertainty associated with future climate projections (Solomon et al. 2007), there is uncertainty in whether the DGVM used in this study can reasonably or accurately simulate future vegetation dynamics over the twenty-first century as there is no direct way to evaluate the future vegetation projections. In addition, uncertainty in predicted vegetation change could arise from the uncertainties in our understanding of 
the mechanisms about climate-induced tree change, particularly regarding the physiological mortality thresholds and interdependencies of the metabolism of carbohydrates, water, and defense (Allen et al. 2010; Fisher et al. 2010; McDowell 2011). The varying results from studies using different DGVMs (e.g., Bergengren et al. 2001; Cox et al. 2004; Jones et al. 2010) highlight the limitations in our understanding of vegetation-climate relationships, and indeed, in understanding vegetation dynamics overall. Vegetation distributions in DGVMs are predicted using simple bioclimatic relationships (temperature and moisture limits) with no barriers to species migration (Higgins and Harte 2006; Alo and Wang 2008). In addition, the impact of insect outbreaks on tree mortality is missing in the current model. Further improvements to DGVMs are needed to better predict vegetation change and mortality mechanistically. Another uncertainty could arise from the prescribed oceanic conditions (or prescribed SSTs). Our simulations used several prescribed oceanic states and were run in an uncoupled framework where vegetation changes cannot feedback to the ocean. Other studies, notably Davin and de Noblet-Ducoudré (2010), found that the climatic impact of land cover change can change the sign of surface temperature change depending on whether or not the ocean is fully coupled to the atmosphere. Future studies allowing the feedbacks among the land, the atmosphere, and the oceans are needed to address vegetation-climate interactions.

Thus, the projections of future vegetation changes in this study must be interpreted with care and should be viewed as providing motivation to better understand climate-vegetation change mechanisms and how they may be incorporated into DGVMs. To that end, research is ongoing to include more sophisticated vegetation mortality mechanisms into earth system models.

Acknowledgments. We thank A. T. Hoang and S. Levis for their help on obtaining CMIP3 data and CLM4 initial data files. Los Alamos National Laboratory LDRD and DOE Office of Science (BER) provided funding for this project. The National Center for Atmospheric Research (NCAR) is operated by the University Corporation for Atmospheric Research under sponsorship of the National Science Foundation.

\section{REFERENCES}

Adams, H. D., M. Guardiola-Claramonte, G. A. Barron-Gafford, J. C. Villegas, D. D. Breshears, C. B. Zou, P. A. Troch, and T. E. Huxman, 2009: Temperature sensitivity of droughtinduced tree mortality portends increased regional die-off under global-change-type drought. Proc. Natl. Acad. Sci. USA, 106, 7063-7066.
—, A. K. Macalady, D. D. Breshears, C. D. Allen, N. L. Stephenson, S. R. Saleska, T. E. Huxman, and N. G. McDowell, 2010: Climate-induced tree mortality: Earth system consequences. Eos, Trans. Amer. Geophys. Union, 91, 153, doi:10.1029/ 2010EO170003.

— drought- and infestation-triggered tree die-off: Insights and hypotheses. Ecohydrology, 5, 145-159, doi:10.1002/eco.233.

Allen, C. D., and Coauthors, 2010: A global overview of drought and heat-induced tree mortality reveals emerging climate change risks for forests. For. Ecol. Manage., 259, 660-684.

Allison, N. L., and Coauthors, 2009: The Copenhagen Diagnosis, 2009: Updating the World on the Latest Climate Science. The University of New South Wales Climate Change Research Centre, $60 \mathrm{pp}$.

Alo, C. A., and G. Wang, 2008: Potential future changes of the terrestrial ecosystem based on climate projections by eight general circulation models. J. Geophys. Res., 113, G01004, doi:10.1029/2007JG000528.

Arora, V. K., and G. J. Boer, 2006: Simulating competition and coexistence between plant functional types in a dynamic vegetation model. Earth Interact., 10. [Available online at http:// EarthInteractions.org.]

Barnett, T. P., and Coauthors, 2008: Human-induced changes in the hydrology of the western United States. Science, 319, 10801083.

Beck, P. S. A., and Coauthors, 2011: Changes in forest productivity across Alaska consistent with biome shift. Ecol. Lett., 14, 373379, doi:10.1111/j.1461-0248.2011.01598.x.

Bentz, B. J., and Coauthors, 2010: Global climate change and bark beetles of the Western United States and Canada: Direct and indirect effects. Bioscience, 60, 602-613.

Bergengren, J. C., S. L. Thompson, D. Pollard, and R. M. Deconto, 2001: Modeling global climate-vegetation interactions in a doubled $\mathrm{CO}_{2}$ world. Climatic Change, 50, 31-75.

Betts, R. A., 2006: Forcing and feedbacks by land ecosystem changes on climate change. J. Phys. IV, 139, 119-142.

Bonan, G. B., 2008: Forests and climate change: Forcings, feedbacks, and the climate benefits of forests. Science, 320, 1444 1449.

_ - and S. Levis, 2006: Evaluating aspects of the Community Land and Atmosphere Models (CLM3 and CAM3) using a Dynamic Global Vegetation Model. J. Climate, 19, 2290-2301.

,,-- L. Kergoat, and K. W. Oleson, 2002: Landscapes as patches of plant functional types: An integrating concept for climate and ecosystem models. Global Biogeochem. Cycles, 16, 1021, doi:10.1029/2000GB001360.

,,-- S. Sitch, M. Vertenstein, and K. W. Oleson, 2003: A dynamic global vegetation model for use with climate models: Concepts and description of simulated vegetation dynamics. Global Change Biol., 9, 1543-1566.

Brekke, L. D., M. D. Dettinger, E. P. Maurer, and M. Anderson, 2008: Significance of model credibility in estimating climate projection distributions for regional hydroclimatological risk assessments. Climatic Change, 89, 371-394, doi:10.1007/ s10584-007-9388-3.

Breshears, D. D., and Coauthors, 2005: Regional vegetation die-off in response to global-change-type drought. Proc. Natl. Acad. Sci. USA, 102, 15 144-15 148.

Cayan, D., M. Tyree, and Coauthors, 2009: Climate change scenarios and sea level rise estimates for the California 2008 climate change scenarios assessment. PIER Research Rep. CEC-500-2009-014, 64 pp. 
—, T. Das, D. W. Pierce, T. P. Barnett, M. Tyree, and A. Gershunov, 2010: Future dryness in the southwest US and the hydrology of the early 21st century drought. Proc. Natl. Acad. Sci. USA, 107, 21 271-21 276.

Chambers, J., J. I. Fisher, H. Zeng, E. L. Chapman, D. B. Baker, and G. C. Hurtt, 2007: Hurricane Katrina's carbon footprint on Gulf Coast forests. Science, 318, 1107.

Chapin, F. S., and Coauthors, 2005: Role of land surface changes in Arctic summer warming. Science, 310, 657-660.

Churkina, G., and S. W. Running, 1998: Contrasting climatic controls on the estimated productivity of global terrestrial biomes. Ecosystems, 1, 206-215.

Ciais, P., and Coauthors, 2005: Europe-wide reduction in primary productivity caused by the heat and drought in 2003. Nature, 437, 529-533.

Cook, E. R., C. M. Woodhouse, C. M. Eakin, D. M. Meko, and D. W. Stahle, 2004: Long-term aridity changes in the western United States. Science, 306, 1015-1018.

Cox, P. M., 2001: Description of the 'TRIFFID' Dynamic Global Vegetation Model. Hadley Centre Tech. Note No. 24, 16 pp.

- , R. A. Betts, M. Collins, P. P. Harris, C. Huntingford, and C. D. Jones, 2004: Amazonian forest dieback under climatecarbon cycle projections for the 21st century. Theor. Appl. Climatol., 78, 137-156.

Davin, E. L., and N. de Noblet-Ducoudré, 2010: Climatic impact of global-scale deforestation: Radiative versus nonradiative processes. J. Climate, 23, 97-112.

Delbart, N., P. Ciais, J. Chave, N. Viovy, Y. Malhi, and T. Le Toan, 2010: Mortality as a key driver of the spatial distribution of aboveground biomass in Amazonian forest: Results from a Dynamic Vegetation Model. Biogeosciences, 7, 3027-3039, doi:10.5194/bg-7-3027-2010.

Edburg, S. L., J. A. Hicke, D. M. Lawrence, and P. E. Thornton, 2012: Simulating coupled carbon and nitrogen dynamics following bark beetle outbreaks. J. Geophys. Res., 116, G04033, doi:10.1029/2011JG001786.

Euskirchen, S. E., A. D. McGuire, and F. S. Chapin III, 2007: Energy feedbacks of northern high-latitude ecosystems to the climate system due to reduced snow cover during 20th century warming. Global Change Biol., 13, 2425-2438, doi:10.1111/ j.1365-2486.2007.01450.x.

Fisher, R., and Coauthors, 2010: Assessing uncertainties in a second-generation dynamic vegetation model caused by ecological scale limitations. New Phytol., 187, 666-681.

Friedlingstein, P., and Coauthors, 2010: Update on $\mathrm{CO}_{2}$ emissions. Nat. Geosci., 3, 811-812.

Gent, P. R., and Coauthors, 2011: The Community Climate System Model, version 4. J. Climate, 24, 4973-4991.

Goetz, S. J., A. G. Bunn, G. J. Fiske, and R. A. Houghton, 2005: Satellite-observed photosynthetic trends across boreal North America associated with climate and fire disturbance. Proc. Natl. Acad. Sci. USA, 102, 13 521-13 525.

Gotangco Castillo, C. K., S. Levis, and P. Thornton, 2012: Evaluation of the new CNDV option of the Community Land Model: Effects of dynamic vegetation and interactive nitrogen on CLM4 means and variability. J. Climate, 25, 3702 3714.

Harris, J. A., R. J. Hobbs, E. Higgs, and J. Aronson, 2006: Ecological restoration and global climate change. Restor. Ecol., 14, $170-176$.

Hicke, J. A., and Coauthors, 2011: Effects of biotic disturbances on forest carbon cycling in the United States and Canada. Global Change Biol., 18, 7-34, doi:10.1111/j.1365-2486.2011.02543.x.
Higgins, P. A. T., and J. Harte, 2006: Biophysical and biogeochemical responses to climate change depend on dispersal and migration. Bioscience, 56, 407-417.

Hurrell, J. W., J. J. Hack, D. Shea, J. M. Caron, and J. Rosinski, 2008: A new sea surface temperature and sea ice boundary data set for the Community Atmosphere Model. J. Climate, 21, 5145-5153.

Hurtt, G. C., S. Frolking, M. G. Fearon, B. Moore, E. Shevliakova, S. Malyshev, S. W. Pacala, and R. A. Houghton, 2006: The underpinnings of land-use history: Three centuries of global gridded land-use transitions, wood harvest activity, and resulting secondary lands. Global Change Biol., 12, 1208-1229.

Jones, C., S. Liddicott, and J. Lowe, 2010: Role of terrestrial ecosystems in determining $\mathrm{CO}_{2}$ stabilization and recovery behaviour. Tellus, 62B, 682-699, doi:10.1111/j.1600-0889. 2010.00490.x.

Joos, F., I. C. Prentice, S. Sitch, R. Meyer, G. Hooss, G. K. Plattner, S. Gerber, and K. Hasselmann, 2001: Global warming feedbacks on terrestrial carbon uptake under the Intergovernmental Panel on Climate Change (IPCC) emission scenarios. Global Biogeochem. Cycles, 15, 891-907, doi:10.1029/ $2000 \mathrm{~GB} 001375$.

Kurz, W. A., C. C. Dymond, G. Stinson, G. J. Rampley, E. T. Neilson, A. L. Carroll, T. Ebata, and L. Safranyik, 2008a: Mountain pine beetle and forest carbon feedback to climate change. Nature, 452, 987-990.

— , G. Stinson, G. J. Rampley, C. C. Dymond, and E. T. Neilson, 2008b: Risk of natural disturbances makes future contribution of Canada's forests to the global carbon cycle highly uncertain. Proc. Natl. Acad. Sci. USA, 105, 1551-1555.

Lamarque, J. F., and Coauthors, 2010: Historical (1850-2000) gridded anthropogenic and biomass burning emissions of reactive gases and aerosols: Methodology and application. Atmos. Chem. Phys., 10, 7017-7039, doi:10.5194/acp-10-7017-2010.

Lawrence, D. M., and Coauthors, 2011: Parameterization improvements and functional and structural advances in version 4 of the Community Land Model. J. Adv. Model. Earth Sys., 3, M03001, doi:10.1029/2011MS000045.

Lawrence, P. J., and T. N. Chase, 2007: Representing a new MODIS consistent land surface in the Community Land Model (CLM3.0). J. Geophys. Res., 112, G01023, doi:10.1029/ 2006JG000168.

- and Coauthors, 2012: Simulating the biogeochemical and biogeophysical impacts of transient land cover change and wood harvest in the Community Climate System Model (CCSM4) from 1850 to 2100. J. Climate, 25, 3071-3095.

Le Quéré, C., and Coauthors, 2009: Trends in sources and sinks of carbon dioxide. Nat. Geosci., 2, 831-836.

Levis, S., G. B. Bonan, M. Vertenstein, and K. Oleson, 2004: The Community Land Model's Dynamic Global Vegetation Model (CLM-DGVM): Technical description and user's guide. NCAR Tech. Note TN-4591IA, 50 pp.

Li, W. H., R. Fu, and R. E. Dickinson, 2006: Rainfall and its seasonality over the Amazon in the 21st century as assessed by the coupled models for the IPCC AR4. J. Geophys. Res., 111, D02111, doi:10.1029/2005/JD006355.

Lin, J. L., 2007: Interdecadal variability of ENSO in 21 IPCC AR4 coupled GCMs. Geophys. Res. Lett., 34, L12702, doi:10.1029/ 2006GL028937.

Liu, S., and Coauthors, 2011: Simulating the impacts of disturbances on forest carbon cycling in North America: Processes, data, models, and challenges. J. Geophys. Res., 116, G00K08, doi:10.1029/2005JD006355. 
McDowell, N. G., 2011: Mechanisms linking drought, hydraulics, carbon metabolism, and mortality. Plant Physiol., 155, 10511059.

— D. J. Beerling, D. D. Breshears, R. A. Fisher, K. F. Raffa, and M. Stitt, 2011: The interdependence of mechanisms underlying climate-driven vegetation mortality. Trends Ecol. Evol., 26, 523-532, doi:10.1016/j.tree.2011.06.003.

Meehl, G. A., and Coauthors, 2007a: The WCRP CMIP3 multimodel dataset. Bull. Amer. Meteor. Soc., 88, 1383-1394.

— Change 2007: The Physical Science Basis, S. Solomon et al., Eds., Cambridge University Press, 747-845.

_ W. M. Washington, J. M. Arblaster, A. Hu, H. Teng, C. Tebaldi, W. G. Strand, and J. B. White III, 2011: Climate system response to external forcings and climate change projections in CCSM4. J. Climate, 25, 3661-3683.

Michaelian, M., E. H. Hogg, R. J. Hall, and E. Arsenault, 2011: Massive mortality of aspen following severe drought along the southern edge of the Canadian boreal forest. Global Change Biol., 17, 2084-2094.

Mote, P. W., 2006: Climate-driven variability and trends in mountain snowpack in western North America. J. Climate, 19, 6209-6220.

— A. F. Hamlet, M. P. Clark, and D. P. Lettenmaier, 2005: Declining mountain snowpack in western North America. Bull. Amer. Meteor. Soc., 86, 39-49.

Nakićenović, N., and Coauthors, 2000: Special Report on Emissions Scenarios. Cambridge University Press, $570 \mathrm{pp}$.

Neale, R. B., and Coauthors, 2010: Description of the NCAR Community Atmosphere Model (CAM 4.0). NCAR Tech. Note NCAR/TN-485+STR, 212 pp. [Available online at http:/www.cesm.ucar.edu/models/ccsm4.0/cam/docs/description/ cam4_desc.pdf.]

Notaro, M., S. Vavrus, and Z. Liu, 2007: Global vegetation and climate change due to future increases in $\mathrm{CO}_{2}$ as projected by a fully coupled model with dynamic vegetation. J. Climate, 20, 70-90.

Oleson, K. W., and Coauthors, 2008: Improvements to the Community Land Model and their impact on the hydrological cycle. J. Geophys. Res., 113, G01021, doi:10.1029/2007JG000563.

- and Coauthors, 2010: Technical description of version 4.0 of the Community Land Model (CLM). NCAR Tech. Note NCAR/TN-478+STR, 257 pp. [Available online at http:// www.cesm.ucar.edu/models/cesm1.0/clm/CLM4_Tech_Note. pdf.]

Pacala, S. W., and Coauthors, 2001: Consistent land and atmospherebased US carbon sink estimates. Science, 292, 2316-2320.

Peñuelas, J., T. Rutishauser, and I. Filella, 2009: Phenology feedbacks on climate change. Science, 324, 887-888.

Pfeifer, E. M., J. A. Hicke, and A. J. H. Meddens, 2011: Observations and modeling of aboveground tree carbon stocks and fluxes following a bark beetle outbreak in the western United States. Global Change Biol., 17, 339-350.

Potter, C. S., S. A. Klooster, R. Nemani, V. Genovese, S. Hiatt, M. Fladeland, and P. Gross, 2006: Estimating carbon budgets for U.S. ecosystems. Eos, Trans. Amer. Geophys. Union, 87, 85-96, doi:10.1029/2006EO080001.

Potter, K. N., H. A. Torbert, H. B. Johnson, and C. R. Tischler, 1999: Carbon storage after long-term grass establishment on degraded soils. Soil Sci., 164, 718-725.

Priestley, C. H. B., and R. J. Taylor, 1972: On the assessment of surface heat flux and evaporation using large-scale parameters. Mon. Wea. Rev., 100, 81-92.
Qian, T., A. Dai, K. E. Trenberth, and K. W. Oleson, 2006: Simulation of global land surface conditions from 1948 to 2004. Part I: Forcing data and evaluations. J. Hydrometeor., 7, 953975.

Raffa, K. F., B. H. Aukema, B. J. Bentz, A. L. Carroll, J. A. Hicke, M. G. Turner, and W. H. Romme, 2008: Cross-scale drivers of natural disturbances prone to anthropogenic amplification: the dynamics of bark beetle eruptions. Bioscience, 58, 501-517.

Rauscher, S. A., J. S. Pal, N. S. Diffenbaugh, and M. M. Benedetti, 2008: Future changes in snowmelt-driven runoff timing over the western US. Geophys. Res. Lett., 35, L16703, doi:10.1029/ 2008 GL034424.

— , F. Kucharski, and D. B. Enfield, 2011: The role of regional SST warming variations in the drying of meso-America in future climate projections. J. Climate, 24, 2003-2016.

Regonda, S. K., B. Rajagopalan, M. Clark, and J. Pitlick, 2005: Seasonal cycle shifts in hydroclimatology over the western United States. J. Climate, 18, 372-384.

Ropelewski, C. F., and M. S. Halpert, 1986: North American precipitation and temperature patterns associated with the El Niño/Southern Oscillation (ENSO). Mon. Wea. Rev., 114, 2352-2362.

Running, S. W., 2008: Ecosystem disturbance, carbon, and climate. Science, 321, 652-653.

Scurlock, J. M. O., K. Johnson, and R. J. Olson, 2002: Estimating net primary productivity from grassland biomass dynamics measurements. Global Change Biol., 8, 736-753.

Seager, R., and G. A. Vecchi, 2010: Greenhouse warming and the 21st century hydroclimate of southwestern North America. Proc. Natl. Acad. Sci. USA, 107, 21 277-21 282.

— , and Coauthors, 2007: Model projections of an imminent transition to a more arid climate in southwestern North America. Science, 316, 1181-1184, doi:10.1126/science. 1139601.

Seppälä, R., A. Buck, and P. Katila, Eds., 2009: Adaptation of Forests and People to Climate Change: A Global Assessment Report. IUFRO World Series, Vol. 22, International Union of Forest Research Organizations, 224 pp.

Seth, A., S. A. Rauscher, M. Rojas, A. Giannini, and S. J. Camargo, 2011: Enhanced spring convective barrier for monsoons in a warmer world. Climate Change Lett., 104, 403-414, doi:10.1007/s10584-010-9973-8.

Sitch, S., and Coauthors, 2003: Evaluation of ecosystem dynamics, plant geography and terrestrial carbon cycling in the LPJ dynamic global vegetation model. Global Change Biol., 9, 161-185.

— , and Coauthors, 2008: Evaluation of the terrestrial carbon cycle future plant geography and climate-carbon cycle feedbacks using five Dynamic Global Vegetation Models (DGVMs). Global Change Biol., 14, 2015-2039, doi:10.1111/ j.1365-2486.2008.01626.x.

Solomon, S., D. Qin, M. Manning, Z. Chen, M. Marquis, K. Averyt, M. Tignor, and H. L. Miller Jr., Eds., 2007: Climate Change 2007: The Physical Science Basis. Cambridge University Press, 996 pp.

Stephenson, N. L., 1990: Climatic control of vegetation distribution: The role of the water balance. Amer. Nat., 135, 649670.

Stewart, I. T., D. R. Cayan, and M. D. Dettinger, 2005: Changes toward earlier stream flow timing across western North America. J. Climate, 18, 1136-1155.

Thonicke, K., S. Venesky, S. Sitch, and W. Cramer, 2001: The role of fire disturbance for global vegetation dynamics: Coupling 
fire into a Dynamic Global Vegetation Model. Global Ecol. Biogeogr., 10, 661-667.

Thornton, P. E., J. F. Lamarque, N. A. Rosenbloom, and N. M. Mahowald, 2007: Influence of carbon-nitrogen cycle coupling on land model response to $\mathrm{CO}_{2}$ fertilization and climate variability. Global Biogeochem. Cycles, 21, GB4018, doi:10.1029/ 2006GB002868.

van Mantgem, P. J., and Coauthors, 2009: Widespread increase of tree mortality rates in the western United States. Science, 323, 521-524.

van Oldenborgh, G. J., S. Y. Philip, and M. Collins, 2005: El Niño in a changing climate: A multi-model study. Ocean Sci., 1, 81-95.

Westerling, A. L., H. G. Hidalgo, D. R. Cayan, and T. W. Swetnam, 2006: Warming and earlier spring increases western U.S. forest wildfire activity. Science, 313, 940-943.

Williams, A. P., C. D. Allen, C. I. Millar, T. W. Swetnam, J. Michaelsen, C. J. Still, and S. W. Leavitt, 2010: Forest response to increasing aridity and warmth in the southwestern United States. Proc. Natl. Acad. Sci. USA, 107, 21 289-21 294.
- C. G. Xu, and N. G. McDowell, 2011: Who is the new sheriff in town regulating boreal forest growth? Environ. Res. Lett., 6, 041004, doi:10.1088/1748-9326/6/4/041004.

— , and Coauthors, 2013: Temperature as a potent driver of regional forest drought stress and tree mortality. Nat. Climate Change, 3, 292-297, doi:10.1038/nclimate1693.

Winton, M., 2006: Amplified Arctic climate change: What does surface albedo feedback have to do with it? Geophys. Res. Lett., 33, L03701, doi:10.1029/2005GL025244.

Xie, S. P., C. Deser, G. A. Vecchi, J. Ma, H. Teng, and A. T. Wittenberg, 2010: Global warming pattern formation: Sea surface temperature and rainfall. J. Climate, 23, 966-986.

Zeng, X. B., X. Zeng, and M. Barlage, 2008: Growing temperate shrubs over arid and semiarid regions in the NCAR Dynamic Global Vegetation Model (CLM-DGVM). Global Biogeochem. Cycles, 22, GB3003, doi:10.1029/ $2007 \mathrm{~GB} 003014$.

Zhao, M., and S. W. Running, 2010: Drought-induced reduction in global terrestrial net primary production from 2000 through 2009. Science, 329, 940-943. 